\title{
Can My Religion Influence My Conception of Justice? Political Liberalism and the Role of Comprehensive Doctrines
}

\author{
Paul Billingham* \\ St Anne's College and Department of Politics and International Relations, University of \\ Oxford, $U K$
}

This is an Accepted Manuscript of an article forthcoming in Critical Review of International Social and Political Philosophy. Online First version available here:

http://www.tandfonline.com/doi/full/10.1080/13698230.2015.1013734.

\begin{abstract}
In his last works, John Rawls explicitly argued for an overlapping consensus on a family of reasonable liberal political conceptions of justice, rather than just one. This 'Deep Version' of political liberalism opens up new questions about the relationship between citizens' political conceptions, from which they must draw and offer public reasons in their political advocacy, and their comprehensive doctrines. These questions centre on whether a reasonable citizen's choice of political conception can be influenced by her comprehensive doctrine. In this paper I present two models of the relationship, which give contrasting answers to these questions, and defend the model that is more permissive with regard to the influence of comprehensive doctrines. This has important implications for our understanding of Rawlsian political liberalism, and reduces the force of objections that have been offered by theorists sympathetic to religion.
\end{abstract}

Keywords: comprehensive doctrines; legitimacy; overlapping consensus; political liberalism; John Rawls

Many objections to John Rawls's political liberalism have come from theorists sympathetic to religion. Their central complaint is that Rawls's view is incompatible with living a 'religiously integrated life' (Wolterstorff 1997). ${ }^{1}$ Whether this objection is valid turns in part on the precise relation between citizens' political conceptions of justice, from which they

\footnotetext{
*Email: paul.billingham@politics.ox.ac.uk
} 
draw and offer public reasons to justify their advocacy of, and votes for, laws relating to fundamental political questions, ${ }^{2}$ and their comprehensive doctrines (including their religious beliefs). That relationship is the focus of this paper. I present two models of the relationship within what Gerald Gaus (2014) calls the 'Deep Version' of Rawlsian political liberalism, and defend the model that is more permissive with regard to the influence of comprehensive doctrines.

The Deep Version of political liberalism recognises reasonable pluralism about justice, not merely about the good. There is a 'family' of reasonable political conceptions of justice, with different (reasonable) citizens accepting different members of that family. This raises the question that is the focus of this paper: can citizens' comprehensive doctrines permissibly influence their choice of political conception? For example, a Catholic citizen who believes that only men can be priests might on this basis reject any political conception that favours laws prohibiting male-only priesthoods. Similarly, a citizen who endorses liberation theology, so believes that God has a preferential concern for the poor, might on this basis endorse a political conception that calls for very high levels of redistribution. The Permissive Model, as I call it, allows this. Citizens can choose their political conception of justice in light of their comprehensive doctrine. According to the Restrictive Model, however, this undermines the freestandingness of citizens' political conceptions, stymies political deliberation, and allows laws to be unacceptably shaped by comprehensive doctrines. Citizens should develop their political conceptions in a freestanding way, insulated from the influence of their comprehensive doctrines.

I will argue that the Permissive Model is compatible with the core tenets of Rawlsian political liberalism and makes possible a more effective response to some of political liberalism's critics. 
The paper proceeds as follows. In the next section I review the basic features of Rawlsian political liberalism, to show how our question arises. I then explain the Restrictive and Permissive Models in detail. Next, I consider five objections to the Permissive Model. Each of these objections draws on some central value or purpose of Rawlsian political liberalism. I argue that the Permissive Model can be defended from these objections. Finally, I present two further considerations in favour of the Permissive Model, which give Rawlsian political liberals reason to accept it in favour of the Restrictive Model. ${ }^{3}$

\section{Setting out the question: basic elements of the Rawlsian picture}

Gaus has recently distinguished between the 'Shallow' and 'Deep' Versions of political liberalism. According to the former, there is reasonable pluralism about the good, due to the burdens of judgment, which are the 'many hazards involved in the correct (and conscientious) exercise of our powers of reason and judgment' (p. 56). ${ }^{4}$ These include the facts that evidence is conflicting and complex, that values can be weighed in different ways, that concepts are vague, that our assessment of evidence is shaped by our total life experiences, and that different normative considerations often conflict (pp. 56-57). For these reasons, the exercise of reason under free institutions leads to deep and irreconcilable disagreements over questions of the good, such that citizens endorse a great diversity of comprehensive doctrines. ${ }^{5}$ The Shallow Version of political liberalism seeks to show that an overlapping consensus on a shared political conception of justice is nonetheless possible among all reasonable citizens.

Citizens are conceived as accepting two sets of values, a political set and a nonpolitical set. ${ }^{6}$ While reasonable pluralism infects the non-political set, leading citizens to accept a variety of comprehensive doctrines, all reasonable citizens can come to share the 
same account of the political set, so share a conception of justice. 'Citizens' overall views have two parts: one part can be seen to be, or coincide with, the publicly recognised political conception of justice; the other part is a (fully or partially) comprehensive doctrine to which the political conception is in some manner related' (p. 38). Some reasonable comprehensive doctrines provide support for the political conception, others are congruent with it, and still others at least avoid direct conflict with it (p. 140). ${ }^{7}$ We thereby achieve a stable and wellordered liberal society, where 'everyone accepts, and knows that everyone else accepts, the very same principles of justice' (p. 35). The political set of values is itself derived from ideas implicit in the public political culture of liberal societies, particularly the idea 'of society as a fair system of social cooperation between free and equal persons' (p. 9). The shared political conception interprets and orders the political values contained within this 'fundamental organising idea' (p. 9).

The Deep Version of political liberalism recognises that the burdens of judgment also affect citizens' beliefs about justice. There is reasonable pluralism about the right, not merely the good. There is no uniquely reasonable way to interpret and weigh the values contained within the political set. Instead, 'there are different and incompatible liberal political conceptions' (p. xlvii) that are nonetheless reasonable. Rawls calls this the 'family of reasonable liberal conceptions of justice' (pp. xlviii, 450). The content of public reason is given by this family of conceptions (p. 453). The Deep Version therefore 'does not try to fix public reason once and for all in the form of one favoured political conception of justice' (p. 451).

Rawls outlines six criteria that a conception of justice must fulfil in order to qualify as a reasonable political conception. In order to be reasonable it must include what Jonathan Quong (2011, pp. 175-180) calls the 'three general liberal principles': 'first, a specification of certain rights, liberties, and opportunities (of a kind familiar from democratic regimes); 
second, a special priority of these freedoms; and third, measures assuring all citizens, whatever their social position, adequate all-purpose means to make intelligent and effective use of their liberties and opportunities' (p. xlvi, cf. 450). ${ }^{8}$

In order for a conception to 'fall under the category of the political' (p. 452), it must be the case that its 'principles apply to basic political and social institutions', that it 'can be presented independently from comprehensive doctrines of any kind' (so is 'freestanding'), and that it 'can be worked out from fundamental ideas seen as implicit in the public political culture of a constitutional regime, such as the conceptions of citizens as free and equal persons, and of society as a fair system of cooperation' (p. 453). Conceptions with these three features contain only political values and apply only to political life, so do not directly compete with the non-political values of comprehensive doctrines. Being freestanding also means that a conception is not ineliminably tied to any one comprehensive doctrine, so citizens holding to different doctrines can accept it.

There is therefore a bounded set of reasonable political conceptions of justice, $\{\mathrm{C} 1$, $\mathrm{C} 2, \ldots, \mathrm{Cn}\}$. Each conception interprets and orders shared political values in a different way. Given the range of possible interpretations and relative weights of political values this will be a large set, but it will nonetheless be limited, since every conception must have the six features that Rawls lists. This is necessary because reasonable political conceptions must be ones that all citizens can be reasonably expected to recognise as reasonable (p. 446). This is an implication of the criterion of reciprocity, which states that citizens must be prepared to offer one another fair terms of social cooperation, where fair terms are understood as ones that the citizen offering them can 'reasonably think that those citizens to whom such terms are offered might also reasonably accept' (p. xlii, cf. 446). Citizens who base their political action on a reasonable political conception fulfil this criterion, and thus offer one another public reasons, fulfilling their 'duty of civility' (pp. 444-447). 
According to the Deep Version, the overlapping consensus is therefore on the family of reasonable political conceptions of justice (p. 164). All the members of this family are recognised as reasonable by every reasonable citizen, but each citizen personally endorses one member of the family, which they take to be the most reasonable conception. ${ }^{9}$ When all reasonable citizens base their political advocacy on such a conception, the reciprocity condition is fulfilled, political legitimacy is achieved, ${ }^{10}$ and a stable political order is established.

Citizens also seek to integrate their political conception, their political set of values, with their comprehensive doctrine, their non-political set, as a module within that broader worldview. It is left to individual citizens to work out how to do this, and what adjustments need to be made to their overall view in order to make it possible.

One aspect of the Deep Version that is as yet unclear, however, is what influence, if any, citizens' comprehensive doctrines can have upon their political conception. Are citizens permitted to shape their conception of justice to enable it to fit with their comprehensive doctrine? To put the question another way, can a citizen choose her political conception from set $\{\mathrm{C} 1, \mathrm{C} 2, \ldots, \mathrm{Cn}\}$ based upon which is most consistent with her comprehensive doctrine? For instance, can she look at the policy implications of various conceptions and then choose the one that fits best with the policy views she derives from her comprehensive doctrine? Or must she work up her conception of justice without any reference to her comprehensive doctrine, bracketing out its influence at this stage in her reasoning?

The next section presents two models of the relationship between citizens' political and non-political sets of values, which give contrasting answers to these questions.

\section{Two models of the relationship between comprehensive doctrines and political conceptions}




\section{The restrictive model}

According to the Restrictive Model, each citizen must deliberate about the interpretation and ordering of political values, and come to endorse a reasonable political conception of justice, independently of her comprehensive doctrine. Reasonable citizens recognise that their political conception must be able to be justified independently from their comprehensive doctrine, so that it provides reasons for laws that all can appreciate as having normative force. They thus develop their political conception in a freestanding way, before seeking to situate it within their broader worldview. When they reject one conception of justice in favour of another, therefore, they do so on the basis of reasons internal to the political set, rather than on the basis of non-political values. They accept a reasonable political conception, and reject other such conceptions, on the basis of public reasons - reasons that all citizens can reasonably be expected to endorse. ${ }^{11}$

\section{The permissive model}

According to the Permissive Model, comprehensive doctrines can influence citizens' reasoning about which political conception they consider most reasonable. While citizens must base their political advocacy and votes on a political conception of justice, and so offer public reasons for laws, their choice of that particular political conception over the alternatives can be partly based upon their comprehensive doctrine. The process of bringing their political set and non-political set of values into congruence with one another is not simply a case of accommodating the latter to an understanding of the former that they developed in a freestanding way. Instead, their non-political values can influence their understanding of political values. When considering competing interpretations of political values, and different ways they can be prioritised and weighed in relation to one another, citizens are permitted to consider insights and arguments drawn from their comprehensive 
doctrine. If a citizen finds that her comprehensive doctrine is incompatible with a particular political conception, $\mathrm{C}_{1}$, then she is permitted to reject $\mathrm{C}_{1}$. Similarly, her comprehensive doctrine might seem particularly well-matched to $C_{2}$, and she is permitted to embrace $C_{2}$ on that basis.

\section{What the models share}

Both models function within the Deep Version of Rawlsian political liberalism. They therefore share four vital features.

First, they share a conception of reasonableness. Both follow Rawls's definition of the beliefs that a citizen must hold in order to be reasonable (see pp. 48-58) and of the features that a conception of justice must have in order to be a reasonable political conception (which I outlined above).

Second, both models require citizens to endorse a complete political conception of justice (pp. 454-455). Citizens' political conceptions must contain a complete account of the various political values, and be applied consistently across different political questions. Completeness means that citizens can draw conclusions on (nearly) all fundamental political questions by sole reference to their political conception, and should support or oppose laws on this basis - on the basis of the public reasons provided by their political conception.

This prevents citizens from drawing on public reasons in an ad hoc way. Without a complete conception of justice, a citizen might form her views on each political question by consulting her religious doctrine, and then appeal in her public advocacy to whatever public reasons happen to support her positions. Rawls is opposed to this.

One problem with 'ad hoc reasoning' is that it can lead to inconsistent uses of political values. Jane believes that her religion supports law $\mathrm{L}_{1}$, which restricts freedom in some way, and appeals to security, a political value, in order to provide public reasons for her 
position. She opposes law $\mathrm{L}_{2}$, also on the basis of her religious views, despite $\mathrm{L}_{2}$ restricting (similar amounts of) freedom for the sake of (similar amounts of) security. In her public advocacy against $L_{2}$, Jane plays down the importance of security and emphasises the importance of freedom, in order to publicly justify her religiously-determined position. If Jane endorsed a complete political conception and applied it consistently across the range of fundamental political questions, she would be forced to choose to either support or oppose both of $\mathrm{L}_{1}$ and $\mathrm{L}_{2}$. Instead, she draws on public reasons in an inconsistent way in order to support positions she holds due to her religious beliefs. This is impermissible.

In some cases, of course, this kind of inconsistency might not arise. Citizens might find that they can form their views on particular issues by consulting their comprehensive doctrine, while appealing to public reasons in a fairly consistent way when providing public justifications for these positions. At the limit, they might implicitly affirm a complete political conception. Nonetheless, unless they form a complete conception of justice and use it consistently in their consideration of political questions, both models consider citizens to be violating the ideal of public reason. They are failing to guide their conduct by the ideal of offering terms of cooperation they can reasonably expect others to endorse.

The third similarity between the two models is that they follow Rawls's 'wide view' of public reason. Citizens may permissibly appeal to their comprehensive doctrines to support their political positions, subject to the proviso that they offer sufficient public reasons in due course (pp. 462-464). Offering non-public reasons alongside public ones might even have beneficial effects, since it shows other citizens how one's comprehensive doctrine and political conception cohere, so reassures them that one is reasonable and sincere in one's public justifications (Boettcher 2005, p. 130).

The desire for citizens' comprehensive doctrines and political conceptions to cohere is the final thing the models share. Citizens are not called to compartmentalise their lives and 
ignore their comprehensive doctrines when they enter the political sphere. Their conception of justice should be distinct from their comprehensive doctrine, yet consistent with it. Even on the Restrictive Model, citizens should accommodate their political conception within their broader worldview.

\section{How the models differ}

The disagreement between the models concerns precisely how this coherence between political conceptions and comprehensive doctrines comes about.

On the Restrictive Model, citizens choose a conception of justice based on freestanding arguments for particular interpretations and orderings of political values. The considerations that lead a citizen to endorse a particular conception of justice should not depend upon her comprehensive doctrine for their validity, but should themselves be public reasons. Citizens then accommodate their political conception within their comprehensive doctrine as a second stage, and any adjustments they make must be to their comprehensive doctrine and not to their political conception. ${ }^{12}$

The Restrictive Model does allow citizens to see their comprehensive doctrine as providing the 'ultimate grounding' for their political conception. Citizens might believe that their comprehensive doctrine provides the true account of why they ought to be reasonable, and so ought to endorse the ideal of public reason and support laws by appeal to political values. But, according to the Restrictive Model, the reasons for a citizen's endorsement of this particular political conception, rather than a different member of the family of reasonable conceptions, should not be comprehensive. Comprehensive doctrines should not influence citizens in their choice of political conception. A citizen's determination of which political conception they believe to be the most reasonable should instead be based on reasons internal to the political set. 
On the Permissive Model, coherence between one's political conception and comprehensive doctrine comes more directly, since the former is worked out with the latter in view, drawing on reasons that the latter provides. One's reasoning about political values might still lead to amendments in one's understanding of non-political values, but adjustments can also go the other way. One can accept or reject a certain interpretation or weighing of political values on the basis of comprehensive considerations.

The difference between the models, therefore, concerns the considerations that citizens are permitted to draw on when determining which political conception of justice in set $\left\{\mathrm{C}_{1}, \mathrm{C}_{2}, \ldots, \mathrm{C}_{\mathrm{n}}\right\}$ they believe is most reasonable.

To make things clearer, consider the case of Betty. As an orthodox Catholic, Betty believes that only men can be priests. Assume that some reasonable political conceptions endorse laws that prohibit male-only priesthoods, on equality grounds, while other reasonable conceptions weigh the value of freedom of association more highly, so permit such priesthoods. ${ }^{13}$ Betty has a theological objection to laws prohibiting male-only priesthoods, and for that reason will not endorse any political conception that favours such laws. She believes that those conceptions allow equality to outweigh freedom of association too easily. She rejects conception $\mathrm{C}_{1}$ on this basis. Betty ultimately comes to accept a complete, reasonable political conception, $\mathrm{C}_{2}$, that permits male-only priesthoods. She bases her political advocacy on this conception, so offers public reasons for (and against) laws (on this issue, and more generally).

We should be clear that Betty accepts and is motivated by the ideal of public reason. She believes that she must offer her compatriots reasons that she can reasonably expect them to accept. She recognises that reasonable pluralism means that no religious reasons fulfil this criterion, and that she must form a reasonable political conception and base her political advocacy upon it. This is why she engages in the process of reasoning that leads her to 
endorse $\mathrm{C}_{2}$. Further, she does not engage in 'ad hoc reasoning', drawing on whatever public reasons support her comprehensively-based view on each political issue. She accepts and acts upon a complete, reasonable, political conception. She also is ready to abandon comprehensively-based considered convictions that are incompatible with $\mathrm{C}_{2}$. Her endorsement of $\mathrm{C}_{2}$, however, is in part based upon reasons drawn from her Catholicism.

Advocates of the Restrictive Model consider this impermissible, and believe that Betty's comprehensive doctrine has an unacceptable level of influence over her political conception. This claim can be fleshed out in several different ways, drawing on different aspects of Rawlsian political liberalism. One might argue that the Permissive Model violates freestandingness, that it allows political conceptions to be 'puppets' for comprehensive doctrines, that it undermines political deliberation, that it permits insincerity, or that it violates the duty of civility and leads to illegitimate political outcomes. I respond to these objections in turn in the next section.

\section{Defending the Permissive Model}

\section{Freestandingness}

Throughout Political Liberalism Rawls emphasises that political conceptions must be 'presented independently from comprehensive doctrines of any kind' (p. 453). Conceptions that satisfy this criterion are 'freestanding': 'a political conception of justice is what I call freestanding when it is not presented as derived from, or as part of, a comprehensive doctrine' (p. xlii). While citizens should relate their political conception to their comprehensive doctrine, the former is 'presented as freestanding and expounded apart from, or without reference to, any such wider background' (p. 12). Political conceptions are accounts of political values only, and apply only to the basic structure. They are not tied to any specific metaphysical or epistemological doctrines, and must be worked up from ideas 
implicit in the public political culture of liberal society.

This might seem to imply the Restrictive Model. Citizens' political conceptions are only freestanding if they have not accepted them based directly on their comprehensive doctrine. That doctrine must not have been determinative in their favouring one political conception over another. Betty's conduct in the above example is a violation of freestandingness, and so is impermissible.

It is not clear that this is what Rawls has in mind, however. Whenever he talks about political conceptions being freestanding he says it means that they must be capable of being presented as independent from any comprehensive doctrine. In other words, it must be possible to show that the conception contains a reasonable interpretation and balance of political values, taking only those values into account. All citizens can recognise the conception as reasonable. This shows that it has a 'pro tanto justification' (p. 386).

This does not necessarily have restrictive implications for the basis on which individual citizens endorse a political conception, or choose it in favour of the alternatives. $\mathrm{C}_{2}$ can be capable of presentation independent of Betty's comprehensive doctrine even though part of her reason for preferring $\mathrm{C}_{2}$ to $\mathrm{C}_{1}$ is that the former is more compatible with that doctrine. $\mathrm{C}_{2}$ is freestanding so long as it can be justified independently of Betty's doctrine, and so be seen as a reasonable understanding of political values by all reasonable citizens. This can be the case even if Betty's own reasons for endorsing this particular conception include comprehensive ones. Betty's choice is partly based on her comprehensive beliefs, but nonetheless the conception she endorses is freestanding, because it 'can be presented without saying, or knowing, or hazarding a conjecture about, what [comprehensive] doctrines it may belong to, or be supported by' (pp. 12-13).

$\mathrm{C}_{2}$ is freestanding because one can argue that it is a reasonable understanding of the set of political values without appealing to any particular comprehensive doctrine. On the 
issue of male-only priesthoods, for example, it seems reasonable to argue that female citizens can have adequate opportunities and liberties in a society where some voluntary associations exclude them from certain positions of leadership. Further, male-only priesthoods do not deny women's equal political status, so are not incompatible with their free and equal citizenship. Given the importance of citizens being free to pursue their conception of the good, the state should not coercively interfere with the internal workings of voluntary associations, as long as basic liberties or opportunities are not being denied. ${ }^{14}$

Some citizens will be unconvinced by this argument; they might believe that discriminatory employment practices deny women equal status in a way that cannot be overridden by the value of free association, and therefore male-only priesthoods should be legally prohibited. Presumably those who hold to $\mathrm{C}_{1}$ believe this. Nonetheless, all can recognise that $\mathrm{C}_{2}$ contains a reasonable interpretation and ordering of political values, and that it can be presented independently of any particular comprehensive doctrine. Indeed, citizens who do not have any comprehensive reasons to favour male-only priesthoods can believe that they should nonetheless be permitted, and so endorse $\mathrm{C}_{2} \cdot{ }^{15}$ In this sense, $\mathrm{C}_{2}$ has a freestanding justification. This is sufficient for it to be a freestanding political conception, even if some citizens who endorse it, such as Betty, do so partly on the basis of their comprehensive doctrine.

This fits with Rawls's discussion in Lecture 4, Section 8: 'Conception and Doctrines: How Related?' (pp. 168-172), where he considers various ways that reasonable comprehensive doctrines can be related to a political conception. One example involves a citizen who accepts Kantian moral philosophy. 'From within his view', Rawls writes, 'the political conception... can, let us say, be derived'. This citizen regards Kantian philosophy 'as the deductive basis of the political conception' (p. 169). Yet freestandingness is not violated. The political conception is still capable of being presented independently of any 
comprehensive doctrine, even though from within the viewpoint of this citizen it is derived from, and continuous with, Kantianism. This supports my argument that the Permissive Model is consistent with freestandingness.

Even on the Permissive Model, citizens must know that their political conceptions are freestanding, and so be able to present their understanding of political values without appeal to their comprehensive doctrine. In other words, they must know that their political conceptions have a freestanding justification and must endorse that justification. Reasonable citizens are motivated by the ideal of public reason, and so believe they must offer others reasons for laws that those others can reasonably be expected to endorse, which requires that the political conception they draw from has a freestanding justification and thus can be seen as reasonable by all citizens. Betty must endorse the freestanding justification for $\mathrm{C}_{2}$, and indeed can present this to others as an argument in favour of $\mathrm{C}_{2} \cdot{ }^{16}$ She can argue that $\mathrm{C}_{2}$ 's weighting of freedom of association as against equality is reasonable without appealing to her Catholicism, as I did above. This is sufficient for freestandingness. The fact that Betty's own reasoning for $\mathrm{C}_{2}$ relied on her comprehensive doctrine does not prevent that conception from being freestanding. A political conception can be freestanding even if (some of) an individual citizen's reasons for believing it to be the most reasonable conception are not.

\section{The puppet worry}

Rawls might be read as ruling out the Permissive Model within his discussion of completeness in 'The Idea of Public Reason Revisited' ${ }^{17}$ Rawls writes that

\footnotetext{
'the ordering of [political] values is made in light of their structure and features within the political conception itself, and not primarily from how they occur within citizens' comprehensive doctrines. Political values are not to be ordered by viewing them separately and detached from one another or from any definite context. They are not puppets manipulated from behind the scenes by comprehensive doctrines' (p. 454).
} 
This suggests that the way political values are interpreted and ordered within one's political conception must be decided based on public reasons, rather than on what fits best with one's comprehensive doctrine. Citizens must endorse a particular political conception based on freestanding reasoning, independently from comprehensive considerations. Betty is allowing her political conception to be a 'puppet', controlled by her comprehensive doctrine, and this is impermissible.

This passage is not in fact incompatible with the Permissive Model, however. Rawls says that the ordering of political values is not made 'primarily' based on comprehensive considerations, suggesting that such considerations can have some influence on the shape of one's political conception. He then notes that 'the ordering is not distorted by those doctrines provided that public reason sees the ordering as reasonable' (p. 454), and emphasises that reasonableness is the only test for distortion. As long as a citizen accepts a political conception that is within the family of reasonable conceptions we cannot say that her comprehensive doctrine has distorted that conception, even if comprehensive considerations have guided her selection of it. This leaves plenty of room for the Permissive Model.

Further, Rawls's primary concern here is that political conceptions are complete, so are frameworks of thought giving reasonable judgments on every fundamental political question. This prevents citizens from reasoning in an ad hoc way, simply finding public reasons that support whatever policies their comprehensive doctrine endorses. As we saw earlier, both models view this as impermissible. Rawls's next paragraph shows that this is his focus:

\footnotetext{
'What we cannot do in public reason is to proceed directly from our comprehensive doctrine, or a part thereof, to one or several political principles and values, and the particular institutions they support. Instead we are required to first work to the basic ideas of a complete political conception and from there to elaborate its principles and ideals, and to use the arguments they provide' (p. 455).
} 
The Permissive Model concurs. Citizens should first work out a complete political conception, using both public and non-public reasons to decide between competing reasonable conceptions, before applying that conception within their political advocacy. Citizens should not move directly from their comprehensive doctrine to particular principles, institutions, or policies.

This is not to say that Rawls is definitely endorsing the Permissive Model here. One could argue that his use of the word 'primarily' is simply a concession to the fact that reasoning about political conceptions cannot be completely insulated from the influence of comprehensive doctrines. The ideal is still that it should not be affected by them. The 'distortion test' would then be a test for checking that others' political conceptions have not been excessively shaped by their comprehensive doctrines. Judging this based on the reasonableness of their conception is the best we can do. When reasoning to one's own political conception, however, one should seek to use only freestanding reasons. This passage can therefore be read as supportive of either model. My claim is simply that it does not clearly rule out the Permissive Model.

Indeed, it is worth noting, as an aside, that I believe that Rawls's own view on the relationship between citizens' comprehensive doctrines and political conceptions within the Deep Version of political liberalism is unclear. While I lack space to show it here, all of his comments that seem relevant to our question can be plausibly read as compatible with either the Restrictive or Permissive Model. This is perhaps unsurprising, since Rawls's realisation that there would be reasonable disagreement about justice within the well-ordered society came late in his turn to political liberalism, as both Gaus (2014) and Paul Weithman (forthcoming) emphasise. Since our question arises only within the Deep Version, ${ }^{18}$ it is not surprising that Rawls never directly addressed it, and said things that suggest contradictory answers to it. ${ }^{19}$ 


\section{Deliberation}

Political liberals place a high value on political deliberation. Citizens should reason together about prospective laws, seeking to understand others' claims and arguments and to justify their own views to one another. They should also be willing to recognise the force of others' arguments, and to revise their political judgments when appropriate. According to the deliberation objection to the Permissive Model, this kind of productive deliberation would be stymied by the fact that citizens accept different political conceptions based on their contrasting comprehensive doctrines. Citizens advocating laws will not be able to persuade their opponents, since the latter's opposition is rooted in their religious and philosophical commitments.

For example, imagine that atheist Alf accepts $C_{1}$, and supports law $L_{1}$, which prohibits male-only priesthoods, on this basis. Betty will reject Alf's public reason argument for $\mathrm{L}_{1}$, and will argue against it by appeal to public reasons drawn from $\mathrm{C}_{2}$. Both citizens can appeal to public reasons in relation to $\mathrm{L}_{1}$. Nonetheless, an advocate of the Restrictive Model can claim that Betty's reliance on her comprehensive doctrine within her political reasoning means that there is no true basis for public deliberation here. Alf can argue that $\mathrm{C}_{1}$ is a better interpretation of political values than $\mathrm{C}_{2}$, and more consistent with the core idea of citizens as free and equal. He can argue that $\mathrm{L}_{1}$ is necessary in order for women to truly be treated as free and equal citizens, and that this cannot be outweighed by the value of citizens' pursuing their conceptions of the good. But Berry has vetoed $\mathrm{C}_{2}$ and $\mathrm{L}_{1}$ based on her religious views, so is not open to such persuasion. Alf and Betty are thus left at a stalemate.

This objection derives its force from a mistaken assumption that every belief influenced by a citizen's comprehensive doctrine is unquestionable and beyond critique. In reality, citizens can still challenge one another's political conceptions, and their views on particular laws, under the Permissive Model. Citizens can question each other's 
interpretations and weightings of political values, both on freestanding grounds and by challenging the claimed connections between their political conception and comprehensive doctrine. Alf might argue both that the strong freestanding arguments in favour of $\mathrm{C}_{1}$ should cause her to favour that political conception and that Betty is incorrect to believe that her religious doctrine gives her reason to reject $\mathrm{C}_{1} \cdot{ }^{20}$ Betty can be open to these arguments, and willing to be persuaded to change her views (either political or comprehensive).

Comprehensive doctrines are not simply unquestionable authorities, especially when it comes to their political implications. Indeed, there will likely be debate among those holding the same comprehensive doctrine as to what political conceptions it is (in)compatible with. Citizens with the same religious beliefs often have widely divergent political views, and debate these on both religious and freestanding grounds. Citizens can be open to reasoned exchange, critique, and persuasion, even when their comprehensive doctrines and political conceptions are connected in the way the Permissive Model allows.

\section{Sincerity}

Many political liberals endorse a sincerity requirement, according to which citizens must believe that the reasons that they offer others for (or against) laws are public reasons and are sufficient to justify (or defeat) those laws (p. 446, Schwartzman 2011). Citizens should not manipulate one another, by offering reasons that they do not personally find persuasive, simply in order to persuade others.

An advocate of the Restrictive Model might argue that public deliberation under the Permissive Model will not be sincere. Betty objects to $\mathrm{L}_{1}$ on the basis of public reasons drawn from $\mathrm{C}_{2}$. She might also offer Alf a freestanding justification for $\mathrm{C}_{2}$, an argument for its weighting of political values that only appeals to public reasons, such as the one I outlined above. She can argue that $\mathrm{L}_{1}$ is objectionable on freedom of association grounds, and show that her political conception interprets and weighs this value in a reasonable way. However, 
her real reasons for endorsing $\mathrm{C}_{2}$, and opposing $\mathrm{L}_{1}$, are religious. She finds the arguments for $\mathrm{C}_{2}$ and against $\mathrm{L}_{1}$ persuasive because of her religious beliefs, yet she presents those arguments to Alf as if they have sufficient independent force. This is insincere.

This objection is strongest in the case where Betty's Catholicism is pivotal in her endorsement of $\mathrm{C}_{2} \cdot{ }^{21}$ This occurs when, counterfactually, she would have accepted $\mathrm{C}_{1}$ had she engaged in freestanding reasoning about political values. If she had examined competing political conceptions independently of her religious beliefs, then she would have considered $\mathrm{C}_{1}$ the most reasonable. For example, she would have concluded that all forms of discrimination within employment decisions violate citizens' equal status, and that appeals to freedom of association cannot outweigh this fundamental political value. Instead, however, Betty takes her Catholic faith into account from the start, allowing it to influence her evaluation of competing reasonable political conceptions, and therefore accepts $\mathrm{C}_{2}$ (and its freestanding justification). In this case, in particular, it might seem insincere for Betty to present arguments based on $\mathrm{C}_{2}$ as sufficient to justify her opposition to $\mathrm{L}_{1}$.

Defenders of the Permissive Model can endorse the sincerity requirement, however, and insist that Betty's deliberation should indeed be sincere. Betty should be open and honest in her deliberation with Alf, and so admit that she has religious reasons for rejecting $\mathrm{C}_{1}$ and favouring $\mathrm{C}_{2}$. She also accepts the freestanding justification for $\mathrm{C}_{2}$, however, and so is not insincere in offering that justification to Alf. She offers Alf public reasons against $\mathrm{L}_{1}$ that she accepts, reasons drawn from $\mathrm{C}_{2}$, and can offer a freestanding justification for $\mathrm{C}_{2}$ that she also accepts. She should be open about the fact that she also has religious reasons to favour $\mathrm{C}_{2}$ over $\mathrm{C}_{1}$.

One might think that the strength of this response depends on whether Betty knows that her Catholicism is pivotal in her endorsement of $\mathrm{C}_{2}$. If she does, then she knows that had she first engaged in freestanding reasoning then she would have endorsed $C_{1}$. It is therefore 
insincere for her to claim that $\mathrm{C}_{2}$ is the most reasonable political conception, or to endorse its freestanding justification, since she really believes that $\mathrm{C}_{1}$ is the most reasonable conception, on purely political grounds.

This is mistaken, however. Betty is certainly sincere if she does not know that her Catholicism is pivotal, but I think she is still being sincere if she does know this. She believes that $\mathrm{C}_{2}$ is the most reasonable political conception, all things considered - that it is the most plausible and well-justified interpretation and ordering of political values, and one that provides reasons that all reasonable citizens can reasonably be expected to accept. Further, in actuality Betty does accept the freestanding justification for $\mathrm{C}_{2}$. She believes that $\mathrm{C}_{2}$ contains the most reasonable weighting of the political values, and that all citizens can recognise $\mathrm{C}_{2}$ as reasonable on freestanding grounds, and this is crucial to her own endorsement of $\mathrm{C}_{2}$. She would reject $\mathrm{C}_{2}$ if it could not be accepted by non-Catholics. Given that it can be, she can sincerely endorse $\mathrm{C}_{2}$ and its freestanding justification, and offer those arguments to Alf, while also acknowledging that she has further religious reasons which explain her own endorsement of $\mathrm{C}_{2}$ as the most reasonable political conception. She sincerely believes that $\mathrm{L}_{1}$ should not be enacted, and that her arguments against $\mathrm{L}_{1}$ can be accepted by all reasonable citizens. She is thus sincerely presenting public reasons in her political advocacy.

\section{Legitimacy}

A final objection to the Permissive Model is that the influence it allows comprehensive doctrines to have over citizens' choice of political conception directly undermines legitimacy. Even if citizens within the Permissive Model endorse reasonable, complete and freestanding political conceptions, and can engage in sincere public deliberation, citizens' comprehensive doctrines are having an undue influence over their political advocacy, and ultimately over political outcomes. While it is permissible for citizens to show how their comprehensive doctrines and political conceptions are compatible, and to express their comprehensive views 
on political questions alongside their public reasons, public justifications should be free from comprehensive influence. They should only draw reasons, values and arguments that can be accepted by every citizen. Allowing comprehensive doctrines to shape citizens' political conceptions of justice prevents this. This means that citizens do not truly fulfil the duty of civility. Their arguments are not truly acceptable to all citizens. Laws are thus enacted, or defeated, on illegitimate grounds.

Thus, even when Betty presents public reasons for laws, drawn from $\mathrm{C}_{2}$, she is offering reasons that are objectionably rooted in her comprehensive doctrine, since that doctrine is pivotal in her endorsement of $\mathrm{C}_{2}$. If there are many citizens like Betty who vote against $\mathrm{L}_{1}$, such that $\mathrm{L}_{1}$ is not enacted, then their religious views objectionably influence this outcome. These citizens oppose the law on the basis of a political conception that they accept for comprehensive reasons, so $\mathrm{L}_{1}$ 's defeat has been unduly influenced by those reasons, undermining the central Rawlsian ambition that political decisions be made on the basis of reasons that all citizens can accept.

We can draw a further distinction here between Betty's religion causing her (and others like her) to recognise the weight of the freestanding argument for $\mathrm{C}_{2}$, and Betty taking her religion to itself provide reasons for her to endorse $\mathrm{C}_{2}$. It might be that while she would have originally endorsed $\mathrm{C}_{1}$ based on freestanding reasoning, her Catholicism causes her to recognise weakness in the argument for $C_{1}$, and that it underestimates the weight of freedom of association, which tells in favour of $\mathrm{C}_{2}$. In this case, her religion is helping her to recognise the independent weight of the public reasons in favour of $\mathrm{C}_{2}$. Alternatively, Betty might take her Catholicism to directly provide reasons for rejecting $\mathrm{C}_{1}$ and accepting $\mathrm{C}_{2}$, and accept the freestanding justification for $\mathrm{C}_{2}$ only because she already endorses that conception. In this case, she would cease to endorse $\mathrm{C}_{2}$ if she became an atheist, since she would cease to have religious reasons in its favour. Some advocates of the Restrictive Model might consider the 
former case permissible. They would certainly object to the latter case, however, since here Betty's religion is crucial to her endorsement of $\mathrm{C}_{2}$, and this threatens to undermine legitimacy. The Permissive Model allows both cases.

I do not think that this shows that we should reject the Permissive Model, however. Even if Betty's Catholicism is pivotal, and even if she takes it as providing reasons in favour of $\mathrm{C}_{2}$, she still endorses a reasonable political conception for which there is a freestanding justification that she accepts and can offer Alf. The fact that she finds that justification plausible in part due to her already having religious reasons for $\mathrm{C}_{2}$ is a normal part of the process of reflective equilibrium. Comprehensive doctrines should be permitted to play the role within reflective equilibrium that the Permissive Model allows them to play precisely because citizens like Betty can fully satisfy the criterion of reciprocity, offering others reasons they can reasonably expect them to accept. Alf can recognise that $\mathrm{C}_{2}$ is a freestanding, reasonable political conception, providing public reasons for and against laws. He can thus accept that laws that are enacted, or defeated, by appeal to $\mathrm{C}_{2}$ are legitimate. The fact that some citizens endorse $\mathrm{C}_{2}$ partly based on their comprehensive doctrines does not undermine this. What matters is that $\mathrm{C}_{2}$ is a reasonable political conception, providing terms of cooperation that all citizens can reasonably be expected to endorse.

It is important to reemphasise here that Betty is motivated by the ideal of public reason. It is not the case that she just happens to end up endorsing a reasonable political conception, so happens to act in conformity with public reason, without actually being guided or motivated by that ideal. Betty endorses the ideal of public reason, and is committed to acting politically on the basis of a reasonable political conception, in order to offer to others reasons that they can reasonably be expected to endorse. If no reasonable political conceptions permitted male-only priesthoods then she certainly would accept a conception that prohibited them, and would vote in favour of prohibitive laws. She considers it vitally 
important that there is a freestanding justification for $\mathrm{C}_{2}$, showing that all citizens can recognise it as reasonable, and that she accepts that justification and offers it to Alf, while also being open about the influence of her comprehensive doctrine. The fact that counterfactually she would endorse $C_{1}$ instead is, in my view, neither here nor there. In actuality she accepts a reasonable political conception, offers a freestanding justification for it, and supports laws on the basis of it, so on the basis of public reasons. The influence of her comprehensive doctrine in her reasoning about political values does not undermine any of this, or prevent her from fulfilling her duty of civility. It thus does not threaten the legitimacy of political outcomes.

\section{Considerations in favour of the Permissive Model}

The previous section argued that the Permissive Model is fully consistent with many of the core values and aims of Rawlsian political liberalism. In this final section I will present two further considerations that count in favour of the Permissive Model: the facts that it is psychologically more realistic and that it can allay integrity objections to political liberalism.

\section{Psychological realism (and stability)}

According to the Restrictive Model, citizens' interpretations of political values must be made independently of their philosophical and religious commitments. Their understanding of what is demanded by freedom of association, sexual equality, due respect for human life, the ordered reproduction of society over time, human rights, public peace, freedom of religion, and so on, ${ }^{22}$ and of how these values should be weighed against one other, must be determined through freestanding reasoning, insulated from the influence of their comprehensive doctrine. It is very hard to see how this is possible. Clearly some 
comprehensive doctrines will be silent on some of these values. Betty's religious beliefs might not include any conception of what 'public peace' is or demands. Often, however, individuals' comprehensive doctrines will include beliefs and principles that ineluctably guide them in their interpretation of political values. For example, a Christian's view of what constitutes 'due respect' for human life will inevitably be influenced by his faith. As theologian Nigel Biggar (2011, pp. 42-43) claims, disagreement within the overlapping consensus will be rooted in the fact that citizens' 'metanarratives' structure their understandings of their shared political values. The content of public reason cannot float entirely free of its comprehensive origins, since different metanarratives lead to different interpretations of the values within it. $^{23}$

It is logically possible for one to set aside all of one's comprehensive beliefs when reasoning about political values and seeking to determine which interpretations best embody the idea of society as a fair system of cooperation between free and equal citizens. This is extremely demanding, however. It is not something we can expect most citizens to accomplish. ${ }^{24}$ As Biggar implies, the Permissive Model is inevitable, or at least much more psychologically realistic. While such psychological considerations are not decisive, they are a relevant factor in choosing between competing accounts of legitimacy, so this gives us some reason to prefer the Permissive Model.

The work of another theologian, David Hollenbach, provides a useful example here. Based on his Catholic faith, Hollenbach (2002, p. 68) argues for a politics centred on 'an understanding of the common good of a pluralist society,' because the good of individuals, including their freedom, can only be realised through social institutions and relationships. 'Any good of a person that is a real good...is embedded in the good of the community. Conversely, any common good that is a real good is simultaneously the good of persons' (Hollenbach 2002, p. 79). This might sound perfectionist, but Hollenbach's commitment to 
the 'common good' proves to amount to an endorsement of something like a Rawlsian conception of justice. For example, in his discussion of poverty and distributive justice he emphasises the need for all to have adequate resources for genuine participation in society, so that the basic structure embodies solidarity and reciprocity. 'Justice calls for the minimal level of solidarity required to enable all of society's members to live with basic dignity' (Hollenbach 2002, p. 192). The policy implications of this include pursuing fair equality of opportunity and lowering structural and economic barriers that prevent the poor from sharing in the common good. While Hollenbach's arguments are shaped by his religious beliefs and expressed in religiously-inspired language, his view of justice might well fall within the family of reasonable political conceptions.

According to Weithman (2010, pp. 323-335), Rawls's shift to the Deep Version of political liberalism was in fact due to him considering such examples. Weithman presents the case of a 'very fully comprehensive' religious doctrine, which 'includes norms, values, and ideals for all subjects' including political institutions. His example is a religious view focused on the common good of those engaged in social forms. In political society this involves mutual love and tolerance. ${ }^{25}$ This leads to a political conception that is different from justice as fairness, but nonetheless appears reasonable, since it supports liberal and egalitarian outcomes, and so endorses just institutions and basic arrangements. Adherents to this comprehensive doctrine desire to live up to political ideals of conduct, civic friendship and association contained within a reasonable political conception. Weithman argues that Rawls recognised that this kind of very fully comprehensive religious doctrine endorses a reasonable political conception different to justice as fairness, and this is why he moved to speaking of a family of reasonable conceptions.

This argument presupposes the Permissive Model. Adherents of the religious doctrine endorse a political conception that is directly derived from their religious beliefs, but is also 
part of the family of reasonable conceptions. Weithman does not suggest that those accepting this doctrine must set it aside and reason in a freestanding way to a political conception. Instead, as long as the conception they derive from their religion is reasonable, they are permitted to base their political advocacy upon it.

Importantly, Weithman also argues that this is consistent with Political Liberalism's stability argument. All citizens endorse a reasonable political conception and want to live up to its values and ideals as long as others do, so all acting upon their conception of justice is a Nash equilibrium. An overlapping consensus on the family of reasonable political conceptions creates a stable well-ordered society, even when at least some citizens' endorsement of their conception is directly influenced by their comprehensive doctrine. For Weithman, therefore, the Permissive Model can fulfil what he believes to be Rawls's central purpose in Political Liberalism.

\section{Integrity}

The Permissive Model also has one final benefit, which I mentioned in my introduction: it defuses many of the integrity concerns pressed by opponents of political liberalism. Biggar's claim about citizens' metanarratives shaping their understanding of shared political values is not merely about psychological realism. More importantly, it points to the fact that many citizens consider this to be a part of their comprehensive commitments, so believe they are morally obligated to base their understanding of political justice on their comprehensive doctrine (Wolterstorff 1997, p. 105) ${ }^{26}$ The Permissive Model allows them to do so, rather than requiring them to engage in a form of freestanding reasoning that they would consider an objectionable strain on their integrity. Citizens are encouraged to have an integrated existence', while remaining within the constraints of public reason.

Of course, those constraints mean that the Permissive Model still demands that 
citizens give up any ambitions to comprehensively structure laws and institutions on the basis of their comprehensive doctrine. Citizens must also exercise restraint, refraining from supporting laws for which their only reasons are non-public. Citizens will sometimes have comprehensive reasons in favour of laws that their political conception cannot justify. The duty of civility demands that they do not seek the enactment of such laws. This is the cost of living in a free, pluralistic, society. But it is a cost that many citizens will be willing to pay, and falls far short of the gross restrictions on religious freedom that some critics have accused Rawls of endorsing. The Permissive Model is consistent with reasonable religious citizens living a religiously integrated life, in a way that the Restrictive Model is not, precisely because it allows them to base their understanding of political values upon their comprehensive beliefs.

\section{Conclusion}

The move to the Deep Version of political liberalism, which acknowledges reasonable disagreement about justice, not only about the good, opens up new questions about the relationship between citizens' comprehensive doctrines and their political conceptions of justice that have been inadequately explored by Rawlsians thus far. In this paper I have presented two models of this relationship and argued that Rawlsians should accept the Permissive Model.

These two models are of course ideal-types, and some theorists might consider the Restrictive Model too restrictive, while also remaining sceptical about some of the forms of reasoning permitted by the Permissive Model. I believe that Rawlsians should fully embrace the Permissive Model, however. This model achieves Rawls's central purpose - providing an account of how a stable and just society of free and equal citizens, living together on fair terms of cooperation by enacting laws acceptable to all, is possible in a pluralistic democracy. 
Being clear that they endorse this model might also mean that Rawlsians win over some of their critics, especially those who have considered political liberalism too restrictive of religious belief in public life.

\section{Acknowledgements}

Versions of this paper were presented in Oxford and Warwick. Many thanks to all who attended on those occasions, and especially to Ian Carroll, Matthew Clayton, Tom Parr, Adam Swift, Anthony Taylor, Stuart White, and Caleb Yong. Thanks also to Kevin Vallier and to two anonymous reviewers from CRISPP for helpful comments on an earlier draft of the paper.

\section{Notes}

1. For discussion, see Boettcher (2005), Neal (2009).

2. 'Constitutional essentials and matters of basic justice'. Rawls restricts the scope of public reason to these areas. All references to 'laws' should be taken to mean laws that fall within the limited domain. Some political liberals reject this restriction of scope. For example, see Quong (2011, pp. 273-289). I will not discuss that debate here. The question I discuss in this paper applies whether one endorses a broad or narrow scope.

3. As is hopefully clear, I am taking the Rawlsian framework as given for the purposes of this paper.

4. All unattributed page numbers in this article refer to Rawls (2005). This version of Political liberalism includes 'The idea of public reason revisited'.

5. Importantly, this is not simple pluralism but reasonable pluralism - a result of citizens' exercises of practical reason (pp. 36-37).

6. It is important to note that when political liberals speak of 'citizens', they usually mean this to refer to agents who are 'idealised' in various ways. While I am agnostic here about what kinds of idealisation are and are not appropriate, all references to 'citizens' in this paper should be taken as referring to agents who are idealised in the appropriate ways.

7. At minimum, no reasonable comprehensive doctrine conflicts 'too sharply' (p. 40) with the political conception.

8. Quong's (2011, pp. 180-187) 'alternative view' of the overlapping consensus sees every reasonable political conception as an interpretation of the three general principles. Rawls simply requires that every conception contain these three principles, alongside other political 
values.

9. For Rawls, this is justice as fairness. Justice as fairness itself is perhaps not a single, welldefined, political conception, however. There are several plausible interpretations of its principles. For instance, primary goods can be weighed against each other in different ways. These differences can have important policy implications (Van Parijs 2003).

10. i.e. the exercise of political power is 'fully proper' (p. 137). This is a lower standard than justice, but a related one (pp. 427-428).

11. Quong's view of the overlapping consensus is a version of the Restrictive Model, but could be amended to fit with the Permissive Model. For criticism of Quong's view, see Zoffoli (2012).

12. This points to a third model, under which citizens must form a political conception in a freestanding way, but can then move to a different conception if they find that it fits better with their comprehensive doctrine. It is likely that the political conception a citizen moves to in this case will be close to the first conception, so the stage of freestanding reasoning is still independently important. In effect, a citizen would narrow down to a subset of reasonable conceptions based on freestanding reasoning, and comprehensive considerations would then determine the precise conception she accepts. While this is a distinct model, it is closer to the Permissive Model in terms of its implications for the relationship between political conceptions and comprehensive doctrines. The arguments for and against the Permissive Model also apply to this third model, which seems to be endorsed by Macedo (2010).

13. If you consider this implausible then feel free to replace the example with an equivalent of your own. I sketch arguments for this claim later in the paper.

14. I am not endorsing this argument. My claim is simply that it appears reasonable, not that it is necessarily correct, or the best understanding of political values.

15. Or some other reasonable political conception that permits male-only priesthoods.

16. An even more permissive model could hold that it does not matter whether Betty accepts the freestanding justification for $\mathrm{C}_{2}$, as long as such a justification exists (and, perhaps, that she knows this), so that $\mathrm{C}_{2}$ is a reasonable political conception, providing public reasons. I think that Rawls would reject this model, however, due to his views of freestandingness, completeness, and publicity. My 'Permissive Model' is the most permissive that Rawls would allow.

17. I was first led to think about the issues explored in this paper by a discussion between Kevin Vallier and Micah Schwartzman on the Public Reason blog: http://publicreason.net/2012/11/26/brettschneider-reading-group-chapter-5-religious-freedomand-the-reasons-for-rights/. Schwartzman cites this passage as the key evidence for his view 
that Rawls favoured the Restrictive Model.

18. The Shallow Version only allows for the Restrictive Model. All reasonable citizens accept the same political conception, so a citizen's comprehensive doctrine cannot affect her choice of conception.

19. Having said this, I think that the trajectory of Rawls's thought, along with several of the pertinent comments in 'Revisited', means that he would endorse the Permissive Model. I lack space to defend this exegetical claim here.

20. This has clear similarities to 'reasoning from conjecture' (pp. 465-466), on which see Schwartzman (2012).

21. I am indebted to Matthew Clayton and Adam Swift for discussion of the points in the following paragraphs.

22. This list of political values is formed using Rawls's own examples (pp. 243, fn. 32; 474; 480, fn. 82).

23. Hollenbach (2002, pp. 166-168) makes a somewhat similar argument.

24. Indeed, forming a complete political conception and applying it consistently across all fundamental political questions is itself very demanding.

25. This is reminiscent of Hollenbach's view.

26. Hollenbach's work is again a pertinent example.

\section{Note on contributor}

Paul Billingham is currently researching for a $\mathrm{PhD}$ in political theory at The University of Oxford, having previously completed his MPhil and BA there. His work focuses on debates within political liberalism, and responses to political liberalism from Christian theology.

\section{References}

Biggar, N., 2012. Behaving in public: how to do Christian ethics. Grand Rapids, Mich.: W.B. Eerdmans Publishing Company.

Boettcher, J.W., 2005. Public reason and religion. In: T. Brooks and F. Freyehagen, eds. The legacy of John Rawls. London: Continuum, 124-151

Gaus, G., 2014. The turn to a political liberalism. In: J. Mandle and D.A. Reidy, eds. A companion to Rawls. Chichester: Wiley-Blackwell, 235-250. 
Hollenbach, D., 2002. The common good and Christian ethics. Cambridge: Cambridge University Press.

Macedo, S., 2010. Why public reason? Citizens' reasons and the constitution of the public sphere', SSRN e-library. http://papers.ssrn.com/sol3/papers.cfm?abstract_id=1664085 [Accessed 9 June 2014].

Neal, P., 2009. Is political liberalism hostile to religion? In: S.P. Young, ed. Reflections on Rawls: an assessment of his legacy. Farnham: Ashgate, 153-175.

Quong, J., 2011. Liberalism without perfection. Oxford: Oxford University Press.

Rawls, J., 2005. Political liberalism. Expanded edition. New York: Columbia University Press.

Schwartzman, M., 2011. The sincerity of public reason. The journal of political philosophy, 19(4), 375-398.

Schwartzman, M., 2012. The ethics of reasoning from conjecture. Journal of moral philosophy, 9(4), $521-544$

Van Parijs, P., 2003. Difference principles. In: S. Freeman, ed. The Cambridge companion to Rawls. Cambridge: Cambridge University Press, 200-240.

Weithman, P.J., 2010. Why political liberalism? On John Rawls's political turn. Oxford: Oxford University Press.

Weithman, P. J., forthcoming. Legitimacy and the project of Rawls's political liberalism. In: T. Brooks and M. Nussbaum, eds. Rawls's political liberalism. New York: Columbia University Press.

Wolterstorff, N., 1997. The role of religion in decision and discussion of political issues. In: R. Audi and N. Wolterstorff, Religion in the public square: the place of religious convictions in political debate. London: Rowman \& Littlefield, 67-120.

Zoffoli, E., 2012. The place of comprehensive doctrines in political liberalism: on some common misgivings about the subject and function of the overlapping consensus. Res Publica, 18(4), 351366. 